\title{
Baicalin and Baicalein Inhibit Src Tyrosine Kinase and Production of IL-6
}

\author{
Dubravko Jelić, ${ }^{1}$ Agnieszka D. Lower-Nedza, ${ }^{2}$ Adelheid H. Brantner, ${ }^{2}$ Biljana Blažeković, ${ }^{3}$ \\ Baolin Bian, ${ }^{4}$ Jian Yang, ${ }^{4}$ Karmen Brajša, ${ }^{1}$ and Sanda Vladimir-Knežević ${ }^{3}$ \\ ${ }^{1}$ Fidelta Ltd., Prilaz Baruna Filipovića 29, 10000 Zagreb, Croatia \\ ${ }^{2}$ Institute of Pharmaceutical Sciences, Department of Pharmacognosy, University of Graz, Universitaetsplatz 4/1, \\ 8010 Graz, Austria \\ ${ }^{3}$ Department of Pharmacognosy, Faculty of Pharmacy and Biochemistry, University of Zagreb, Marulićev Trg 20/II, \\ 10000 Zagreb, Croatia \\ ${ }^{4}$ Institute of Chinese Materia Medica, China Academy of Chinese Medical Sciences, No. 16 Nanxiaojie, \\ Dongzhimennei Avenue, Dongcheng District, Beijing 100700, China
}

Correspondence should be addressed to Sanda Vladimir-Knežević; svladimir@pharma.hr

Received 26 October 2015; Revised 23 February 2016; Accepted 2 March 2016

Academic Editor: Gabriel Navarrete-Vazquez

Copyright (๑) 2016 Dubravko Jelić et al. This is an open access article distributed under the Creative Commons Attribution License, which permits unrestricted use, distribution, and reproduction in any medium, provided the original work is properly cited.

Flavonoids play an important role in the treatment of various diseases, as they are able to inhibit reactive oxygen species, which cause damage to cells and tissues which may lead to increased risk of inflammatory diseases. Baicalin and baicalein, two flavonoids found in the roots of Scutellaria baicalensis, in the leaves of Thymus vulgaris and Oroxylum indicum, were tested for their anti-inflammatory activity as well as for their cytotoxicity. Thereby the two compounds were investigated on Src tyrosine kinase inhibition and inhibition of production of interleukin (IL-6) in lipopolysaccharide- (LPS-) stimulated THP-1 cells. Additionally, the THP-1 cell line was used for the determination of the cytotoxicity. Both baicalin and baicalein showed some anti-inflammatory properties, while baicalein turned out to be the more active compound with higher inhibitory activities on both Src tyrosine kinase and production of cytokine IL-6. Baicalin and baicalein showed no signs of cytotoxicity in the MTS cytotoxicity assay in THP-1 cells.

\section{Introduction}

Inflammatory mediators (IM) are produced as a response for macrophages exposed to pathogens or other harmful stimuli or trauma. This exposure leads to activation of nitric oxide (NO), reactive oxygen species (ROS), or cytokines including various interleukins [1]. The activation results in inflammation processes in cells or tissues. Consequences are tissue damage, leading to diseases like atherosclerosis and pulmonary fibrosis [2], or autoimmune diseases such as multiple sclerosis, rheumatoid arthritis, and systemic lupus erythematosus [3]. IL-6 is a proinflammatory agent produced by various cells, for example, macrophages or neutrophils, and has been considered as a byproduct of ongoing inflammatory processes [4-6]. Together with TNF $\alpha$ and IL-1, IL- 6 is also considered a major proinflammatory cytokine important in the protection from pathogens during an infection. IL-6 is an important modulator of CD4 T cell effector functions thereby shaping the immune response and contributing to inflammation [3]. Recent studies report the inhibitory activity of natural compounds on IL-6 production in vitro $[7,8]$.

Src tyrosine kinase ( $\mathrm{Src}$ ) is a ubiquitously expressed nonreceptor tyrosine kinase belonging to the Src family of kinases [9]. Src family kinases are known for their roles in the progression of cancer; however they are also involved in inflammation-related signaling pathways, proliferation, and chemotaxis $[2,10]$. After stimulation of different types of the receptors, Src plays a critical role in recruiting a number of cell signaling molecules, which results in the induction of various cytokines, including IL-6 [11].

Flavonoids as natural polyphenols are a class of secondary plant metabolites with a wide distribution in fruits and 
<smiles>O=C(O)[C@H]1O[C@@H](Oc2cc3oc(-c4ccccc4)cc(=O)c3c(O)c2O)[C@H](O)[C@@H](O)[C@@H]1O</smiles>

Baicalin<smiles>O=c1cc(-c2ccccc2)oc2cc(O)c(O)c(O)c12</smiles>

Baicalein

FIgURE 1: Chemical structures of baicalin and baicalein, natural flavonoid compounds, both occur naturally in the roots of Scutellaria baicalensis Georgi, as well as in the leaves of Thymus vulgaris L. and Oroxylum indicum (L.) Benth. ex Kurz.

vegetables [12]. Their antioxidant potential is related to their ability to neutralize free radicals in cells [13]. Additionally, flavonoids inhibit $\mathrm{NF} \kappa \mathrm{B}$ and VEGF expression and cause cell toxicity in cancer cells $[14,15]$. Baicalein and baicalin are both natural flavonoid compounds. Baicalein belongs to flavones, a subclass of flavonoids, and baicalin, also known as baicalein7-glucuronide, is its conjugate (Figure 1). Both occur naturally in the roots of Scutellaria baicalensis Georgi, as well as in the leaves of Thymus vulgaris L. and Oroxylum indicum (L.) Benth. ex Kurz [16]. Previous investigations showed antioxidant and anti-inflammatory effects of baicalein and baicalin applying the 2,2-diphenyl-1-picrylhydrazyl (DPPH) radical scavenging, the lipid peroxidation, and tyrosinase inhibition assays [17]. In the present study both substances were tested for their inhibitory activity on Src tyrosine kinase and IL-6 production, as well as for their cytotoxicity in THP-1 cells.

\section{Materials and Methods}

2.1. Reagents. Adenosine $5^{\prime}$-triphosphate disodium salt dehydrate (ATP; A-2383), ethylenediaminetetraacetic acid (EDTA; E-4884), 4-(2-hydroxyethyl)-1-piperazineethanesulfonic acid (Hepes; $\mathrm{H}-3375)$, magnesium chloride $\left(\mathrm{MgCl}_{2}\right)$ (M-8266), ethylene glycol tetraacetic acid (EGTA; E-4884), dimethyl sulfoxide (DMSO) (Hybri-Max ${ }^{\mathrm{TM}}$, sterile-filtered, $\geq 99.7 \%$; D-2650), Tween 20 (27,434-8), staurosporine (S-4400), LPS from Escherichia coli serotype 0111:B4, and bovine serum albumin (BSA; A2153) were obtained from Sigma Chemical Co. (St. Louis, MO, USA), fetal bovine serum (FBS; S04382S1810) was obtained from BioWest, and Immulon $2 \mathrm{HB}$ 96-well plates were obtained from Dynex (UK, 3455). LANCE Ultra ULight-TK peptide (TRF0127M), LANCE ${ }^{\circledR}$ Eu-W1024 anti-phosphotyrosine (PT66; AD0068), LANCE detection buffer 10x (CR97-100), and 384-deep-well Storplate-V (6008590) were purchased from Perkin Elmer. Mouse IL-6 Biotinylated Affinity Purified PAb Goat IgG (antibody with biotin; BAF406) and IL-6 monoclonal antibody (FAB227C) were obtained from R\&D (USA), streptavidin from horse radish peroxidase (OR $03 \mathrm{~L}$ ) was obtained from Calbiochem, USA, and Roswell Park Memorial Institute 1640 medium (RPMI; A10491) was

obtained from Gibco. Dithiothreitol (DTT; 161-0611) was purchased from Bio-Rad, and 384-well plates (flat bottom, small volume, white; 784075) were purchased from Greiner BioOne. THP-1 tumor cell lines were obtained from ECACC (ECACC-88081201), Src (08-173) was obtained from Carna Biosciences, and MTS (CellTiter $96^{\circledR}$ AQueous One Solution Cell Proliferation Assay, Part\#G358B, Lot\#18824201) was obtained from Promega. The pure compounds baicalin and baicalein were purchased from Sigma-Aldrich.

2.2. THP-1 Cell Cultivation. THP-1 tumor cell line was maintained in RPMI 1640 medium supplemented with $10 \%$ fetal bovine serum at $37^{\circ} \mathrm{C}$ in a $5 \% \mathrm{CO}_{2}$ atmosphere.

2.3. LPS-Induced IL-6 Production in THP-1 Cells. Modulation of IL-6 production in LPS-stimulated THP-1 cells by tested compounds (in a final concentration range of $1000-12 \mu \mathrm{g} / \mathrm{mL}$ ) was exhibited using an enzyme-linked immunosorbent assay (ELISA). An inflammatory response was previously induced by using mitogen LPS (in final conc. of $1 \mu \mathrm{g} / \mathrm{mL})$. THP- 1 cells $\left(3 \times 10^{5}\right.$ cells/well $)$ were preincubated with the samples for two hours at $37^{\circ} \mathrm{C}$, in an atmosphere of $5 \% \mathrm{CO}_{2}$ and $90 \%$ humidity, and then treated with LPS overnight at $37^{\circ} \mathrm{C}$ in $5 \% \mathrm{CO}_{2}$. Compounds are prepared from $10 \mathrm{mM}$ DMSO stock solutions; they are diluted 1:2 in cellular media with $1 \mathrm{mg} / \mathrm{mL}$ starting final concentrations. The next day, the supernatant was removed and transferred to the Immulon 2HB 96-well plates. The IL- 6 concentration was measured by using sandwich ELISA. IL-6 monoclonal antibody was bound on the well bottom (hIL-6, $2 \mu \mathrm{g} / \mathrm{mL}$ ); samples and standards were transferred and bound to the antibody in the presence of the cytokine. After washing and blocking with $1 \%$ BSA, the antibody with biotin, bound to the previously bounded cytokine, was added. After incubation and washing, streptavidin was added. The plates were read using an EnVision 2104 plate reader (Perkin Elmer) at $450 \mathrm{~nm}$. The developed color was proportional to the concentration of cytokines and was quantified using standards. Inhibition (as percentage) was calculated using the following formula: $\%$ inhibition $=[1-($ concentration of IL- 6 in sample - concentration of IL- 6 in negative control)/(concentration of IL- 6 in positive control - concentration of IL- 6 in negative control) $\times 100$. The positive control refers to LPS-stimulated samples that were not preincubated with the compounds. The negative control refers to unstimulated and untreated samples. Reference control compound for inhibition of IL6 production was Azithromycin, which showed acceptable standard values for this assay.

2.4. Src Tyrosine Kinase Assay. A time-resolved fluorescence resonance energy transfer (TR-FRET) tyrosine kinase assay was used for testing the inhibitory activity of the samples [18]. The Src kinase assay was performed in low-volume 384well test plates. A mother plate (Storplate-384-deep-well-V plate, Perkin Elmer) with 1:3 serial dilutions $(1 \mathrm{mg} / \mathrm{mL}$ as starting concentrations) of the samples in pure DMSO was prepared from $100 \mathrm{mg} / \mathrm{mL}$ compound stock solutions on the Janus automatic pipetting workstation (JANUS Integrator 
Platform, 8 tips, AJI8001, Perkin Elmer). $100 \mathrm{~nL}$ of the samples was transferred from the mother plate to the test plate by using a nanovolume liquid handling instrument Mosquito (3019-0002, TTP Labtech). The first step initiated the kinase reaction by mixing $5 \mu \mathrm{L}$ of kinase with $5 \mu \mathrm{L}$ of combined peptide substrate $(2.5 \mu \mathrm{L})$ and ATP $(2.5 \mu \mathrm{L})$ and incubating for 3 hours at $20^{\circ} \mathrm{C} \pm 2^{\circ} \mathrm{C}$. $\operatorname{Src}(0.5 \mathrm{nM})$, peptide substrate $(50 \mathrm{nM})$, and ATP $(200 \mu \mathrm{M})$ were diluted in kinase buffer $(50 \mathrm{mM}$ HEPES, $10 \mathrm{mM} \mathrm{MgCl}_{2}$, $1 \mathrm{mM}$ EGTA, $2 \mathrm{mM}$ DTT, and $0.01 \%$ Tween 20). Final concentrations of compounds in the test plate were in a range from $1 \mathrm{mg} / \mathrm{mL}$ to $0.02 \mu \mathrm{g} / \mathrm{mL}$. In the second step, $5 \mu \mathrm{L}$ of EDTA $(10 \mathrm{mM})$ and $5 \mu \mathrm{L}$ of Europium-antiphospho antibody $(1 \mathrm{nM})$ (both prepared in LANCE detection buffer) were added and incubated for 1 hour at $20^{\circ} \mathrm{C} \pm$ $2^{\circ} \mathrm{C}$ and the plates were read at Ex340/Em615-665 with an EnVision (Xcite Multilabel Reader, 2104-0020, Perkin Elmer) plate reader. The concentrations given in brackets refer to final concentrations used in the assay. Total percentage of DMSO in the kinase reaction was $1 \%$. Staurosporine was used as a reference control compound.

2.5. Cytotoxicity Assay. Cytotoxicity of the samples was estimated on human leukemia cells (THP-1) by a modified version of Mosmann [19]. A mother plate (Storplate-384deep-well-V plate, Perkin Elmer) with 1:3 serial dilutions in triplicate $(1 \mathrm{mg} / \mathrm{mL}$ as starting concentrations) of the samples in pure DMSO was prepared from compound stock solutions on the Janus automatic pipetting workstation (JANUS Integrator Platform, 8 tips, AJI8001, Perkin Elmer). $500 \mathrm{~nL}$ of the samples was transferred from the mother plate to the test plate by using a nanovolume liquid handling instrument Mosquito (3019-0002, TTP Labtech). Cells were distributed in 384-well plates, in concentrations of $2 \times 10^{4}$ cells per well, in $50 \mu \mathrm{L}$ of cell culture medium. Cells were incubated in presence of the tested compound for $24 \mathrm{~h}$ at $37^{\circ} \mathrm{C}$. Cell growth was estimated by the [3-(4,5-dimethylthiazol-2-yl)-5-(3carboxymethoxyphenyl)-2-(4-sulfophenyl)-2H-tetrazolium] MTS assay. After adding $5 \mu \mathrm{L}$ of MTS, the plates were incubated for 3 hours. Absorbance at $492 \mathrm{~nm}$ was measured with a plate reader. The total percentage of DMSO in the cytotoxicity assay was $1 \%$. The MTS tetrazolium compound is bioreduced by cells into a colored formazan product that is soluble in tissue culture medium. This conversion is presumably accomplished by NADPH or NADH, produced by dehydrogenase enzymes in metabolically active cells. This enzyme turns the MTS into a different color by cutting the tetrazolium ring. Reference control compound for MTS assay was Azithromycin, which showed acceptable standard values for this assay.

2.6. Data Handling. Calculation of $\mathrm{IC}_{50}$ data, curves, and QC analysis was made by using Excel tools and GraphPad Prism software, v. 5.03. Briefly, individual concentrationeffect curves were generated by plotting the logarithm of the tested concentration of tested compounds $(X)$ versus corresponding percent inhibition values $(Y)$ using least squares (ordinary) fit. Best fit $\mathrm{IC}_{50}$ values were calculated using $\log$ (inhibitor) versus normalized response-variable slope equation, where $Y=100 /\left(1+10^{\left(\left(\log \mathrm{IC}_{50}-X\right) * \text { Hillslope }\right)}\right)$. QC criteria parameters $\left(Z^{\prime}, S: B, R^{2}\right.$, Hillslope) were checked for every $\mathrm{IC}_{50}$ curve.

\section{Results and Discussion}

The process of inflammation is involved in an increasing number of diseases. For this reason it is necessary to develop effective and safe treatments. Steroids are widely prescribed "gold standard" drugs which reduce inflammation by binding to the glucocorticoid receptor. However, due to their known side effects they are often avoided, if possible. Nonsteroidal anti-inflammatory drugs (NSAIDs), which act mainly through the cyclooxygenase (COX) enzyme inhibition, are the most common "nonsteroidal" way to treat various inflammatory diseases. However, their mode of action does not include direct inhibition of cytokine production, and besides their therapeutic effects, they also cause various side effects, also due to inhibition of COX enzymes [20]. Facing these problems, it is necessary to find substances with maximum inhibitory activity of various inflammatory mediators and minimum toxicity and side effects for the patients.

Flavonoids are potent antioxidant compounds with the ability of opposing free radicals damage to DNA, lipids, proteins, and other biomolecules. It is believed that these properties are attributed to the anticancerogenic, antiproliferative, and antiangiogenic activities of flavonoids [2123]. Summarizing the activities of flavonoids, they may be considered as an alternative and natural approach for the treatment of inflammatory diseases. In the present study, baicalin and baicalein were tested for their anti-inflammatory activity in the IL- 6 cytokine and Src tyrosine kinase inhibition assays, as Src is involved in the inflammation process as well as in cancer development $[2,11]$. Both baicalin and baicalein showed significant Src inhibitory activities. Aglycone baicalein inhibited Src tyrosine kinase with $\mathrm{IC}_{50}$ values of $1.2 \mu \mathrm{g} / \mathrm{mL}$ (or $4 \mu \mathrm{M}$, if results are presented in molar concentrations), while the glycoside baicalin inhibited Src with a slightly higher $\mathrm{IC}_{50}$ value of $7.6 \mu \mathrm{g} / \mathrm{mL}$ (or $17 \mu \mathrm{M}$ ) (Figure 2). The obtained results should be taken into consideration for the possible evaluation of baicalin and baicalein for anticancer treatment as well.

Concerning the inhibition of cytokine production, especially the inflammation marker IL-6, baicalin and baicalein were investigated by measuring the IL- 6 production in LPSstimulated THP- 1 cells. The results are displayed in Figure 3. Full inhibitory activity of the level of IL- 6 could be observed for baicalein for the three highest tested concentrations (1000, 333 , and $111 \mu \mathrm{g} / \mathrm{mL}$ ), which would give $\mathrm{IC}_{50}$ value of $88 \mu \mathrm{g} / \mathrm{mL}$ (or $326 \mu \mathrm{M}$ ), whereas baicalin inhibited IL-6 production more significantly only at a highest tested concentration $(1000 \mu \mathrm{g} / \mathrm{mL})$, which would give $\mathrm{IC}_{50}$ value of $578 \mu \mathrm{g} / \mathrm{mL}$, or $1295 \mu \mathrm{M}$. Therefore, this means that baicalin is about 4 times less potent than baicalein also in this assay.

Additionally, cytotoxicity of the two flavonoids was evaluated by using THP-1 cells. The results showed that both baicalin and baicalein had no cytotoxic effect on the THP1 cells after $24 \mathrm{~h}$ at concentrations up to $1000 \mu \mathrm{g} / \mathrm{mL}$, in 


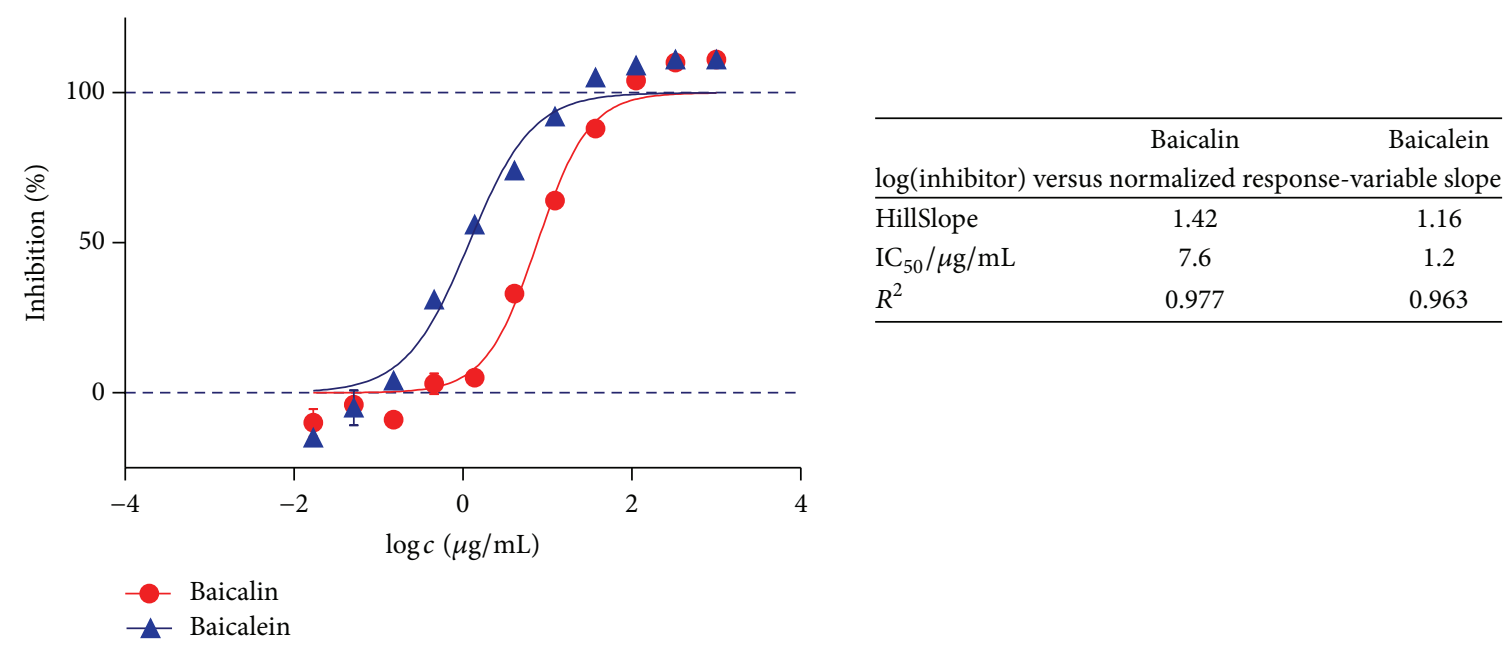

FIGURE 2: Dose-response curves and $\mathrm{IC}_{50}$ values of Src kinase inhibition for baicalin and baicalein. Error bars are representing standard deviations of triplicate average values. If results are presented in molar concentrations (for better comparison of compounds with different MWs), $\mathrm{IC}_{50}$ values would be $17 \mu \mathrm{M}$ for baicalin and $4 \mu \mathrm{M}$ for baicalein.

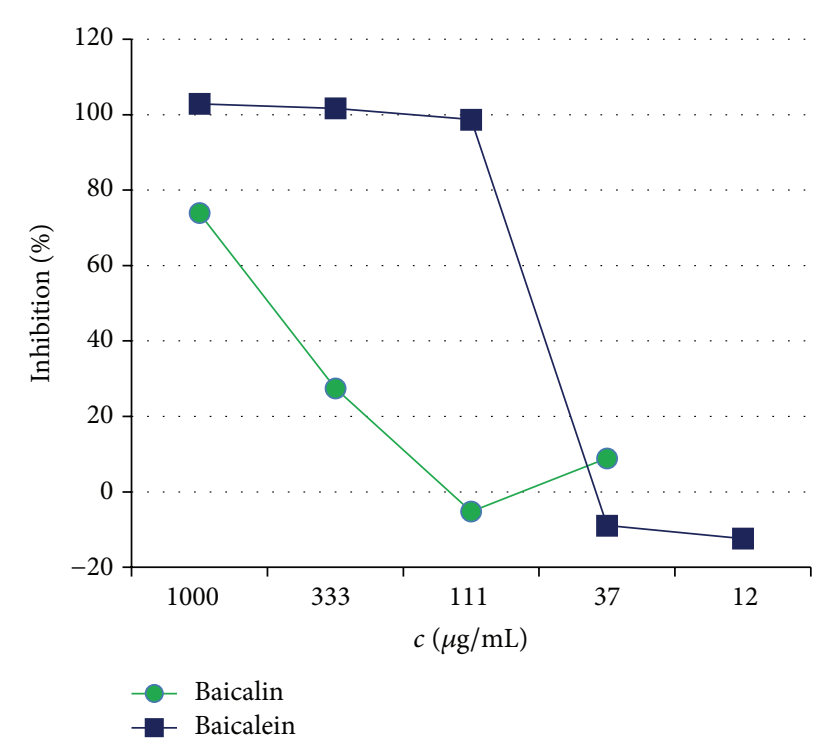

FIGURE 3: Inhibition values of IL-6 production in LPS-stimulated THP-1 cells for the flavonoid compounds baicalin and baicalein. Full inhibitory activity of the level of IL- 6 could be observed for baicalein for the three highest tested concentrations (1000, 333 , and $111 \mu \mathrm{g} / \mathrm{mL}$, which would give $\mathrm{IC}_{50}$ value of $88 \mu \mathrm{g} / \mathrm{mL}$, or $326 \mu \mathrm{M}$ ), whereas baicalin inhibited IL-6 production only at a highest tested concentration $\left(1000 \mu \mathrm{g} / \mathrm{mL}\right.$, which would give $\mathrm{IC}_{50}$ value of $578 \mu \mathrm{g} / \mathrm{mL}$, or $1295 \mu \mathrm{M})$.

comparison to the reference compound staurosporine, used as a cytotoxic positive control of the assay. $\mathrm{IC}_{50}$ values for inhibition of THP-1 cell lines were $>1000 \mu \mathrm{g} / \mathrm{mL}$ for both baicalin $(>2.2 \mathrm{mM}$ in molar concentrations) and baicalein ( $>3.7 \mathrm{mM}$ in molar concentrations). Quite the contrary, a significant level of stimulation of mitochondrial activity of the cells could be observed in this study after $24 \mathrm{~h}$ incubation of cells, but only after incubation with baicalein. This effect

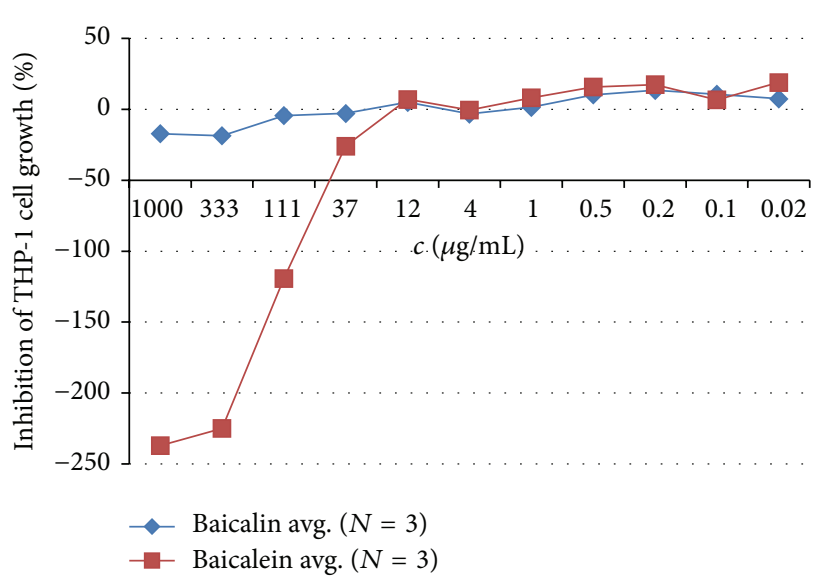

FIGURE 4: Influence of baicalin and baicalein on the viability of THP-1 cell lines. Untreated cells and media only as controls represented 0 or $100 \%$ of inhibition. Significant level of stimulation of mitochondrial activity of the cells could be observed in this study after $24 \mathrm{~h}$ incubation of cells, but only after incubation with baicalein. $\mathrm{EC}_{50}$ value for stimulation of mitochondrial activity for baicalein can be calculated from the dose-response curve, and result is $111 \mu \mathrm{g} / \mathrm{mL}$, or $411 \mu \mathrm{M}$.

is visible in concentrations within $1000 \mu \mathrm{g} / \mathrm{mL}-37 \mu \mathrm{g} / \mathrm{mL}$ $(3700 \mu \mathrm{M}-137 \mu \mathrm{M})$, in a dose-response manner. Since MTS assay was used to evaluate mitochondrial activity of cells, by measuring succinate hydrogenase activity [19], negative values of the tested inhibition of the cell growth represent, in fact, stimulation of cellular mitochondrial activity (Figure 4). Interestingly, this stimulatory effect is visible only with baicalein, which is a compound with more pronounced anti-inflammatory activity. $\mathrm{EC}_{50}$ value for stimulation of mitochondrial activity for baicalein can be calculated from the dose-response curve, and result is $111 \mu \mathrm{g} / \mathrm{mL}$, or $411 \mu \mathrm{M}$ (Figure 4). 
Summarizing the results, it can be concluded that both the aglycone baicalein and the glycoside baicalin showed inhibitory activities in the two different anti-inflammatory assays, on inhibition of Src tyrosine kinase and production of IL-6 cytokine in LPS-stimulated THP-1 cells, with baicalein being much more potent in both assays. These differences may be related to the structure of the flavonoids, since baicalin has the sugar moiety attached to the flavonoid ring, which could be of significant steric hindrance in ligand-receptor interactions, in comparison to the baicalein flavonoid ring. These results can be useful for recognizing important orientation of possible docking/binding of the flavonoids to their receptors. The cytotoxicity profile of both compounds indicates no cytotoxic properties. The results obtained from the present study confirm the antiinflammatory activities of baicalein and baicalin and therefore will be beneficial to further investigation of these flavonoids as an effective new possible treatment option for inflammatory or cancer diseases.

\section{Competing Interests}

The authors have declared no conflict of interests.

\section{Acknowledgments}

The work was supported by the Austrian Federal Ministry of Science and Research and the Austrian Federal Ministry of Health (Project no. 402.000/0002-II/6b/2012), the bilateral project between Austria and Croatia (WTZ HR-02/2012), and the Ministry of Science, Education and Sports of the Republic of Croatia (Project no. 006-0061117-1238). The authors thank Ms. Klara Markušić and Ana Cvetković for technical assistance.

\section{References}

[1] M. Del Donno, D. Bittesnich, A. Chetta, D. Olivieri, and M. T. Lopez-Vidriero, "The effect of inflammation on mucociliary clearance in asthma: an overview," Chest, vol.118, no. 4, pp. 11421149, 2000.

[2] S. E. Byeon, Y.-S. Yi, J. Oh, B. C. Yoo, S. Hong, and J. Y. Cho, "The role of Src kinase in macrophage-mediated inflammatory responses," Mediators of Inflammation, vol. 2012, Article ID 512926, 18 pages, 2012.

[3] O. Dienz and M. Rincon, "The effects of IL-6 on CD4 T cell responses," Clinical Immunology, vol. 130, no. 1, pp. 27-33, 2009.

[4] G. Carbone, A. Wilson, S. A. Diehl, J. Bunn, S. M. Cooper, and M. Rincon, "Interleukin-6 receptor blockade selectively reduces IL-21 production by CD4 T cells and IgG4 autoantibodies in rheumatoid arthritis," International Journal of Biological Sciences, vol. 9, no. 3, pp. 279-288, 2013.

[5] M. Rincon, "Special issue on interleukin-6 (IL-6)," International Journal of Biological Sciences, vol. 8, no. 9, pp. 1225-1226, 2012.

[6] T. Tanaka and T. Kishimoto, "Targeting interleukin-6: all the way to treat autoimmune and inflammatory diseases," International Journal of Biological Sciences, vol. 8, no. 9, pp. 1227-1236, 2012.
[7] K. Jung, Y.-W. Chin, K. D. Yoon et al., "Anti-inflammatory properties of a triterpenoidal glycoside from Momordica cochinchinensis in LPS-stimulated macrophages," Immunopharmacology and Immunotoxicology, vol. 35, no. 1, pp. 8-14, 2013.

[8] K. S. Siveen and G. Kuttan, "Modulation of humoral immune responses and inhibition of proinflammatory cytokines and nitric oxide production by 10-methoxycanthin-6-one," Immunopharmacology and Immunotoxicology, vol. 34, no. 1, pp. 116-125, 2012.

[9] Y.-P. Chong, K. K. Ia, T. D. Mulhern, and H.-C. Cheng, "Endogenous and synthetic inhibitors of the Src-family protein tyrosine kinases," Biochimica et Biophysica Acta, vol. 1754, no. 1-2, pp. 210-220, 2005.

[10] I. Zachary, "VEGF signalling: integration and multi-tasking in endothelial cell biology," Biochemical Society Transactions, vol. 31, no. 6, pp. 1171-1177, 2003.

[11] B. Peruzzi, A. Cappariello, A. Del Fattore, N. Rucci, F. De Benedetti, and A. Teti, "c-Src and IL-6 inhibit osteoblast differentiation and integrate IGFBP5 signalling," Nature Communications, vol. 3, article 630, 2012.

[12] C. Bosetti, M. Rossi, J. K. McLaughlin et al., "Flavonoids and the risk of renal cell carcinoma," Cancer Epidemiology Biomarkers and Prevention, vol. 16, no. 1, pp. 98-101, 2007.

[13] C. A. Gonzalez and E. Riboli, "Diet and cancer prevention: Where we are, where we are going," Nutrition and Cancer, vol. 56, no. 2, pp. 225-231, 2006.

[14] H. Luo, G. O. Rankin, L. Liu, M. K. Daddysman, B.-H. Jiang, and Y. C. Chen, "Kaempferol inhibits angiogenesis and VEGF expression through both HIF dependent and independent pathways in human ovarian cancer cells," Nutrition and Cancer, vol. 61, no. 4, pp. 554-563, 2009.

[15] K. Plochmann, G. Korte, E. Koutsilieri et al., "Structure-activity relationships of flavonoid-induced cytotoxicity on human leukemia cells," Archives of Biochemistry and Biophysics, vol. 460, no. 1, pp. 1-9, 2007.

[16] J. Chen, Z. Li, A. Y. Chen et al., "Inhibitory effect of baicalin and baicalein on ovarian cancer cells," International Journal of Molecular Sciences, vol. 14, no. 3, pp. 6012-6025, 2013.

[17] A. D. Lower-Nedza, C. Kuess, H. Y. Zhao, B. L. Bian, and A. H. Brantner, "In vitro anti-inflammatory and antioxidant potential of Si-Miao-San, its modifications and pure compounds," Natural Product Communications, vol. 8, no. 8, pp. 1137-1141, 2013.

[18] D. J. Moshinsky, L. Ruslim, R. A. Blake, and F. Tang, "A widely applicable, high-throughput TR-FRET assay for the measurement of kinase autophosphorylation: VEGFR-2 as a prototype," Journal of Biomolecular Screening, vol. 8, no. 4, pp. 447-452, 2003.

[19] T. Mosmann, "Rapid colorimetric assay for cellular growth and survival: application to proliferation and cytotoxicity assays," Journal of Immunological Methods, vol. 65, no. 1-2, pp. 55-63, 1983.

[20] S. Harirforoosh, W. Asghar, and F. Jamali, "Adverse effects of nonsteroidal antiinflammatory drugs: an update of gastrointestinal, cardiovascular and renal complications," Journal of Pharmacy and Pharmaceutical Sciences, vol. 16, no. 5, pp. 821847, 2013.

[21] M. Freitas, D. Ribeiro, T. M. Sara, S. M. Artur, and E. Fernandes, "Anti-inflammatory and pro-apoptotic activities of chlorinated flavonoids in human neutrophils," Free Radical Biology \& Medicine, vol. 75, supplement 1, article S30, 2014.

[22] J. C. Menezes, B. Orlikova, F. Morceau, and M. Diederich, "Natural and synthetic flavonoids: structure activity relationship 
and chemotherapeutic potential for the treatment of leukemia," Critical Reviews in Food Science and Nutrition, 2015.

[23] S. Vladimir-Knežević, B. Blažeković, M. B. Štefan, and M. Babac, "Plant polyphenols as antioxidants influencing the human health," in Phytochemicals as Nutraceuticals-Global Approaches to Their Role in Nutrition and Health, V. Rao, Ed., chapter 9, InTech, Rijeka, Croatia, 2012. 

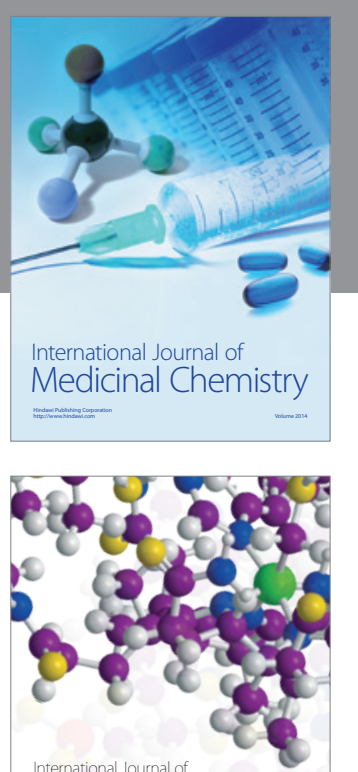

Carbohydrate Chemistry

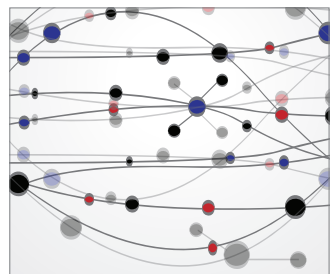

The Scientific World Journal
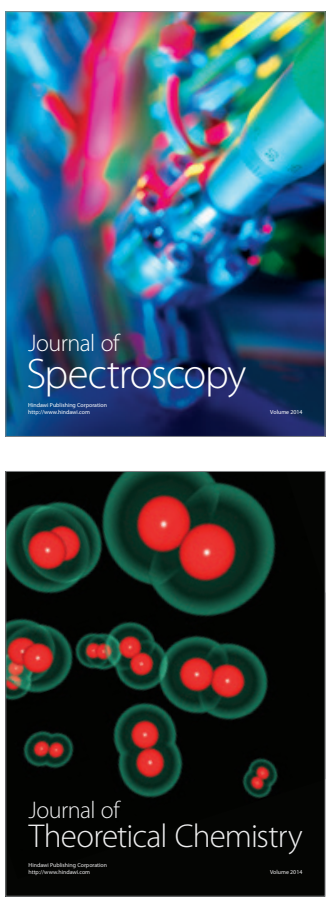
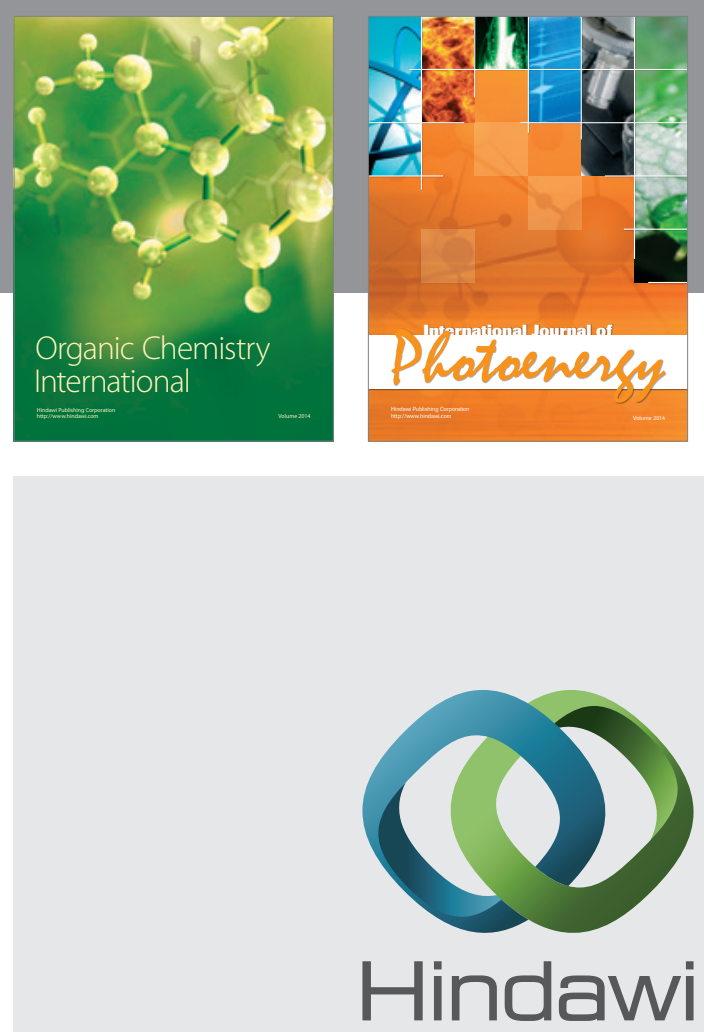

Submit your manuscripts at

http://www.hindawi.com

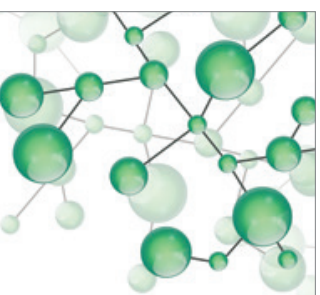

International Journal of

Inorganic Chemistry

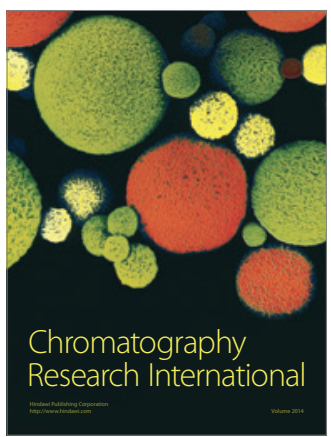

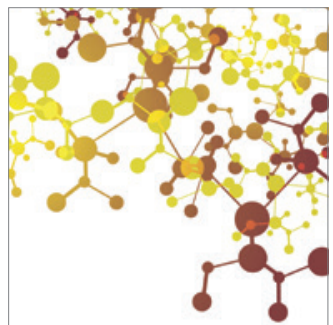

Applied Chemistry
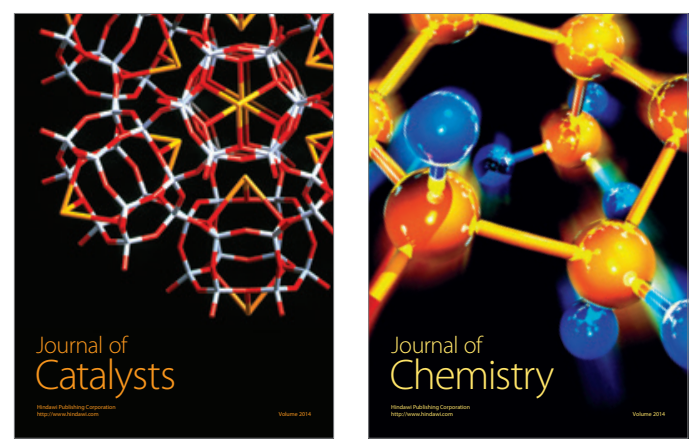
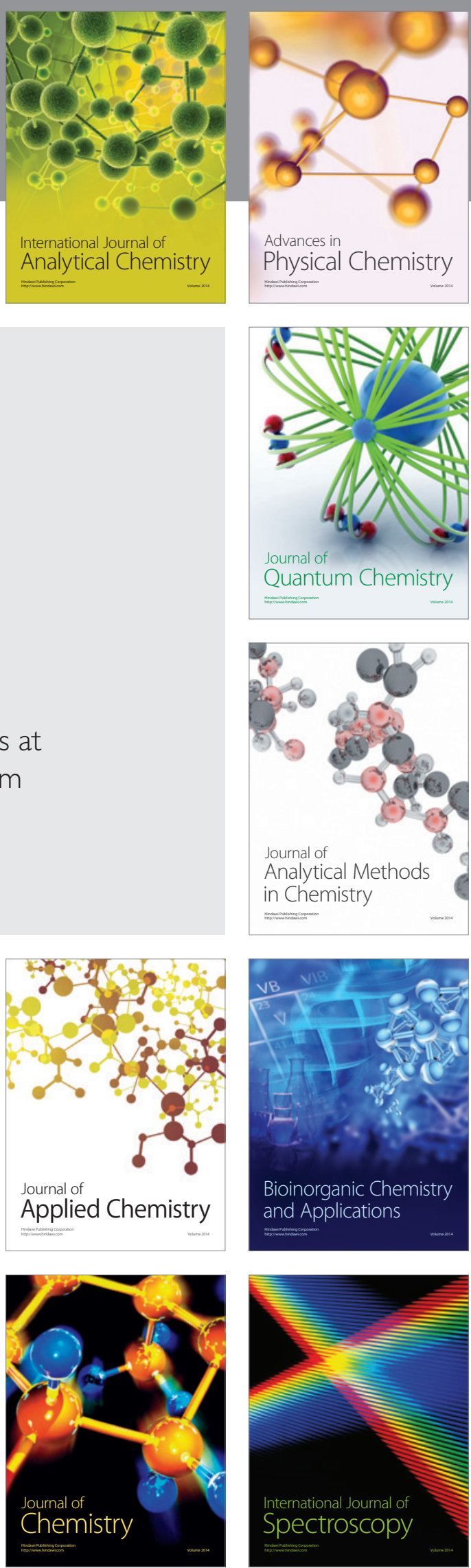